\title{
Growth and Postnatal Development of the European Water Shrew
}

\author{
Iwona MICHALAK
}

\begin{abstract}
Michalak I., 1987: Growth and postnatal development of European water shrew. Acta theriol., 32, 16: 261-288 [With 6 Tables, 8 Figures \& Plates VIII-IX]

Growth and development of 185 young water shrews (27 litters) Neomys fodiens (Pennant, 1771) were studied. Neonates averaged $0.62 \mathrm{~g}$, dorsal skin pigment appeared on the 5th day of life, as did that of the abdomen on the 9 th day. Young shrews first vocalized on the 11 th day, opened their eyes between days $20-24$, and left the nest spontaneously on days 23-25. By 10-11 days they weighed ten times their birth mass, and on the day of nest leaving their mass was 19.4 times greater than at birth. When they left the nest, though some mass loss or arrest of mass gain subsequently occurred. Mass gain resumed when they began eating solid food (between days 27-30). Young water shrews usually nursed to their 38th day of life.

[Mammals Research Institute, Polish Academy of Sciences, 17-230 Białowieża, Poland].
\end{abstract}

\section{INTRODUCTION}

Postnatal development of Soricidae is interesting because these animals are poorly understood, most species have not been bred in captivity, and also because the family is of great interest from the standpoint of mammalian reproductive evolution. Vogel $(1972 \mathrm{a}, \mathrm{b})$ examined postnatal and embryonal development of Neomys fodiens (Pennant, 1771), Sorex araneus Linnaeus, 1758, and Crocidura russula (Hermann, 1780), and concluded that in the family Soricidae the evolution from the primitive nidicolous type (Soricinae) to the evolved nidicolous type (Crocidurinae) was indicated.

The purpose of this study was to further document in a greater number of animals the postnatal development of Neomys fodiens previously studied by Vogel (1972a) and Köhler (1984). Additionally, attention was paid to the individual and interlitter differences between litters of varying number of animals regarding rate of development of external features and of mass gain.

\section{MATERIAL AND METHODS}

Neomys fodiens caught in the Białowieża Primeval Forest were bred in the years 1979-1981 and in 1983. Breeding conditions have been described in an earlier paper (Michalak, 1983). Twenty seven litters yielded 185 young animals of which 117 from 20 litters were raised by their mothers to independence. 
Observations of appearance and behaviour of the young shrews were conducted from birth to about 2 months of age. The nests of the first litters born in captivity were inspected daily; later litters were observed at intervals of $2-3$ days, to ascertain that the course of development was the same as in the more closely monitored litters.

Young shrews were recognized individually by noting their sex and the pattern of dark spots on the ventral side of their bodies (Fedyk \& Borowski, 1980). If two animals were of the same sex and had identical spots on the abdomen, they were marked by coded hair removal.

Mass gain was observed in young of 23 litters. Three litters were weighed only on the first day of life. In 8 other litters young were weighed on the first or second day, thereafter at intervals of $1-3$ days. Animals in the remaining 12 litters were first weighed about the age of 20 days. In the first week of life the whole litters were usually weighed. From the second week of life the shrews were weighed individually, in all cases with an accuracy of $0.02 \mathrm{~g}$. Body measurements were taken to the nearest $0.1 \mathrm{~mm}$ with a slide calliper,

Animals born on a given day were considered as one-day old, without respect to the hour of brith. Ages of animals reported by others were similarly calculated.

Body masses of adult and subadult Neomys fodiens and Neomys anomalus Cabrera, 1907, used for comparison were obtained from animals caught in the Białowieża Forest in the years 1948-1982 (unpublished data).

\section{RESULTS}

\subsection{Appearance and Body Mass of Neonates}

Newborn shrews were nude and dark-red. Blood vessels and viscera were visible through the skin. Umbilical cord was a prominent crust or scab, and the tail was characteristically curved and tucked between the legs to lie on the abdomen.

The mean dimensions (in $\mathrm{mm}$ ) of eight newborns were: body length 20.5 (range: 17.0 to 22.5 ), tail length 5.4 (range: 4.8 to 6.3 ), foot length 3.2 (range: 2.9 to 3.5 ).

Body masses of 9 litters on day 1 are in Table 1 . Mean prenursing body mass in three neonatal litters was $0.62 \mathrm{~g}(\mathrm{n}=34)$.

\subsection{Changes of Appearance}

The general course of postnatal development of young water shrews is illustrated by Plates VIII and IX.

\subsubsection{Umbilical Cord, Vibrissae, Skin Pigmentation, Hair}

Day 2. Pink, naked body. Umbilical cord usually absent but persists in some as a small, flat scab. 
Day 3. Pale pink body. Vibrissae protrude from the skin and can be seen without magnification.

Day 5. Grey pigmentation of the back appears, but the abdomen and paws are pink. Vibrissae $1 \mathrm{~mm}$ long.

Day 6. The back is dark-grey. The distal parts of the crura and proximal parts of the feet are light-grey ("socks"). The distal end of the forearm closely above the palm is very poorly pigmented. In females c.ark spots of pigment mark the sites of nipples (it is possible to recognized the sex of the young).

Days $7-8$. Dorsal pigmentation is darker, the pigmented bands on the extremities are broader.

Day 9. Dorsal hair erupting, in most animals visible only with magnification, and in only a few animals is the back covered with down visible with naked eye. On the abdomen are grey pigment spots, at the sites where dark-coloured fur will appear later.

Table 1

Body mass of newborns $N$. fodiens

\begin{tabular}{lrcccc}
\hline $\begin{array}{c}\text { Litter } \\
\text { No. }\end{array}$ & $\begin{array}{c}\text { Litter } \\
\text { size }\end{array}$ & Hour born & $\begin{array}{c}\text { Hour } \\
\text { weighed }\end{array}$ & $\begin{array}{c}\text { Age of } \\
\text { newborn } \\
(\mathrm{h})\end{array}$ & $\begin{array}{c}\text { Mean body } \\
\text { mass }(\mathrm{g})\end{array}$ \\
\hline $71 \mathrm{I}$ & 15 & 13.00 & 13.00 & $0^{1}$ & 0.53 \\
260 & 9 & 11.30 & 11.30 & 0 & 0.59 \\
315 & 10 & 19.15 & 19.15 & 0 & 0.70 \\
64 & 8 & 9.30 & 10.30 & 1 & $0.51^{2}$ \\
107 & 5 & 16.15 & 22.45 & 6.5 & $0.69^{3}$ \\
308 & 6 & $14.00-23.00^{4}$ & 23.00 & $1-9$ & 0.72 \\
$83 \mathrm{~V}$ & 7 & $11.00-15.00^{4}$ & 20.00 & $5-9$ & 0.82 \\
$83 \mathrm{I}$ & 5 & 10.00 & 23.30 & 13.5 & 0.89 \\
300 & 7 & 23.30 & 19.30 & 20 & 0.80 \\
\hline
\end{tabular}

1 Zero age means that young were weighed immediately after birth they were still wet and without milk in stomach, ${ }^{2}$ Dead, bitten by the male, milk in stomach, ${ }^{3}$ Two dead young, three living but not fed by the female, ${ }^{4}$ Birth hour unknown.

Day 10. In all animals the back is covered with hairs (grey down). Only under the knee joint remains a narrow, light, non-pigmented band of skin. Feet are dark, with the exception of toes. Elbows are flanked by broad bands of non-pigmented skin. Palms are dark only proximally. Abdominal spots are fairly well visible but insufficient for determining precisely the future colour pattern of fur. Evident skin thickening along ventral tail margin (at the site where the keel will form.).

Day 11. Donsal fur $1 \mathrm{~mm}$; barely visible down on abdomen. In some animals ends of keel hairs are discernible.

Day 12. Smooth, lustrous fur on the back; visible down on the abdomen. 
Days 13-14. Abdomen is covered with smooth hair. Posterior extremities are wholly dark, but a very narrow non-pigmented proximal part of the forearm remains.

Days 15-16. Lustrous hair on the abdomen, very clearly visible darkcoloured spots. Forearm completely pigmented.

Days $20-25$. The fur loses its lustre, appears dull and more fluffy. No significant changes in fur occur after day 25 .

\subsubsection{Separation of Digits}

Finger and toe separation occurs between days 13-19 (Fig. 1). On day 13 the fingers were fused in all observed shrews $(n=20)$, as were the toes in all except two animals with partly separated toes IV and V. Digits began separating by day 14 in all animals. Fingers were separated more rapidly than toes. Extreme (I and V) digits separated earliest.
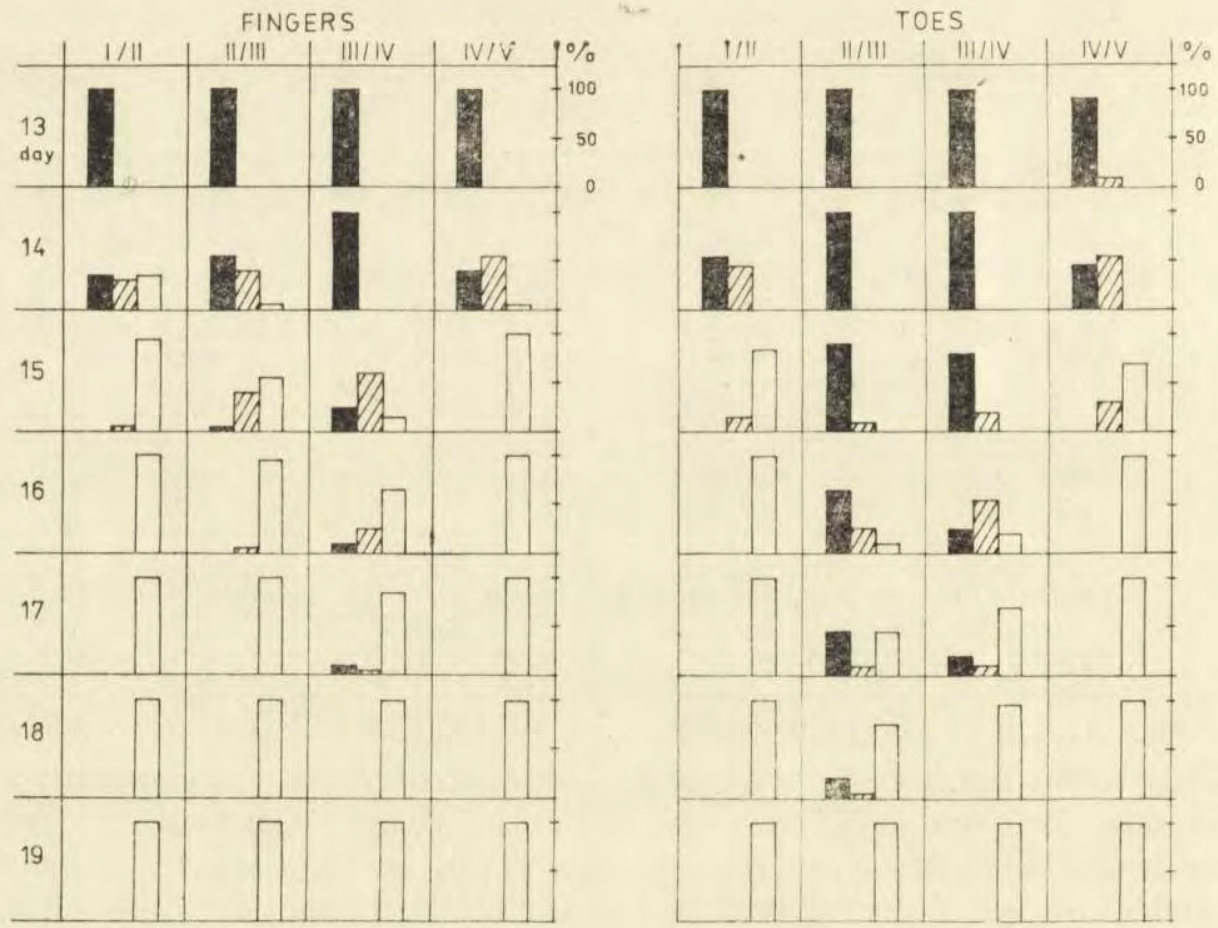

国 $\square z^{\mathrm{b}} \square \mathrm{c}$

Fig. 1. Separation of fingers and toes in $N$. fodiens ( $\mathrm{n}=20$ young from three 1 tters). Columns designate the percent of fingers and toes: (a) completely fused, (b) partly fused, (c) completely separated. 


\subsubsection{Eye Opening}

Eyes open inconsistently between days 20 and 24 (Fig. 2), beginning on: day $20-5$ litters, day $21-7$ litters, day $22-1$ litter. The duration of this process within a litter from appearance of slits between eyelids to full opening of both eyes in all animals was: 1 day ( 2 litters), 2 days (7 litters), 3 days (3 litters), and 4 days (1 litter). All animals in a litter had completely open eyes by day 22 (4 litters), day 23 ( 5 litters), or day 24 (4 litters).

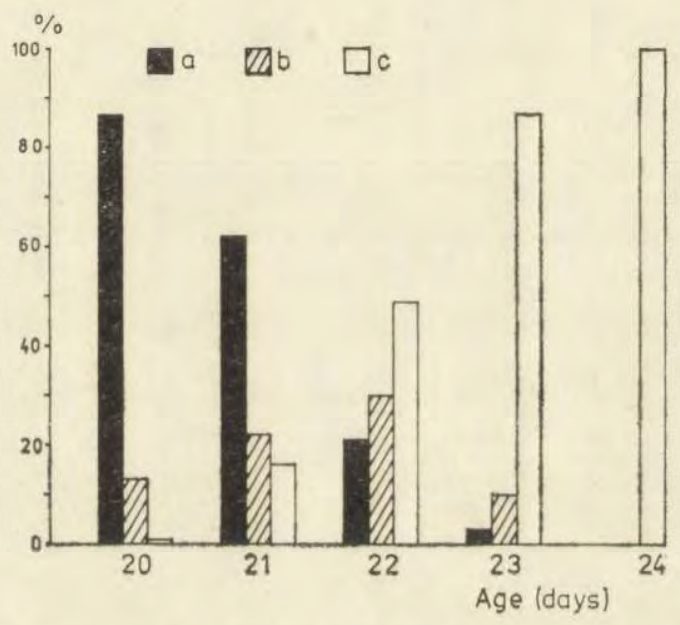

Fig. 2. Opening of eyes in $N$. fodiens ( $\mathrm{n}=85$ young from 13 litters). Columns designate the percent of eyes: (a) closed, (b) with slits between eyelids, (c) completely open.

\subsubsection{Tooth Eruption}

By day 12 gingivae were stretched over incisors, and on day 13 in some animals the tips of incisors were already visible through the gingival mucosa, uppers, lowers or both. Teeth were still in the gingivae during the next 10 days. On day 24 the incisors tips appeared rounded (not sharp), were unerupted and the shrews were not able even to pinch the human fingers although they tried to do so. On the 25th day, at the earliest, the incisors erupted and were sharp, but could not cut the epidermis of the human fingers, though this occurred, although infrequently, two to three days later. It seems that salivation, a characteristic feature at the age of $23-26$ days (the young had wet muzzles), was associated with teeth eruption. 


\subsection{Behaviour Changes}

\subsubsection{Locomotor and Orientative Abilities}

Young animals aged one day taken out of the nest and placed on a smooth surface of a table in prone position changed this position to supine by means of twisting movements of the trunk and pushing the head against the surface. In the supine position they arched the body, elevating the head and the hindquarters, and with additional movements of the trunk they turned and rocked themselves (Fig. 3a). They could not

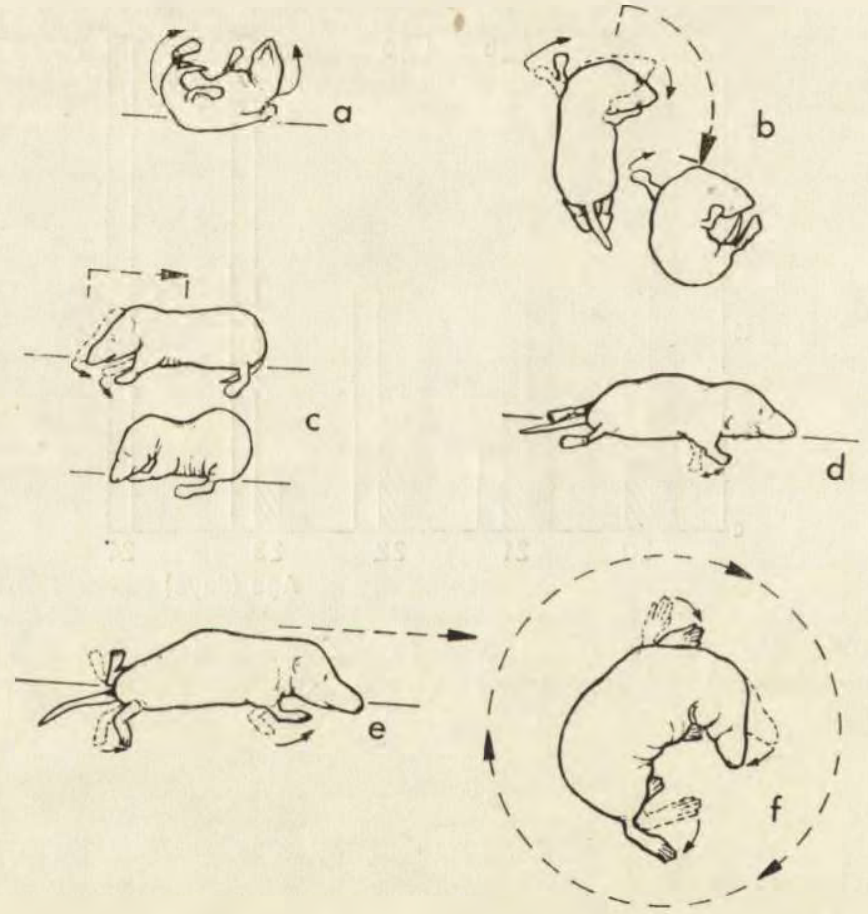

Fig. 3. Development of locomotor ability in nestling $N$. fodiens. Small arrows indicate direction of movements of these parts of the body which actively participate in them, and large arrows indicate direction of movement of whole body (further explanations in text).

yet change the supine position to prone, but could at most change the supine position to lateral decubitus position. After one or two minutes the young became cold (to the touch), immobile and lay on their backs or, less frequently, on side.

On the second day of life some animals could already change the position from supine to prone by rocking violently, and the stronger ones 
could change their position several times, thus roll. Dorsal-up animals could turn through small angles pushing the head against the surface by helping with one forepaw. Hindquarters were pulled during these movements (Fig. 3b). Often they pushed the body backwards with the head and forepaws without moving the hindquarters, thus assuming a hunched position (Fig. 3c).

During days 3 and 4 the movements of the young animals were not significantly changed, they could only change positions easier. But while turning around they frequently lost balance and fell belly up. On days $4-5$ the young while in dorsal-up position could turn around through a $360^{\circ}$ angle (full spinning movement).

Crawling was first observed on day 5 in one out of five observed litters. Only the forepaws participated in this crawling, and the animals flapped them clumsily through small angles in the direction of the anterior part of the body. However, since this "flapping in air" with the forepaws was not accompanied by sufficiently strong pushing against the surface on which they were placed, the animals did not move forwards (Fig. 3d). On days 7 to 9 the young shrews pushed with the forepaws more strongly, but moved forward only slightly losing easily balance, or after several pushing forward movements they began turning around. Meager use of the hindpaws in crawling was observed. However, the animals could not yet pull the hindpaws under the trunk, but trailed them sprawling, moving only the feet (Fig. 3e). At one week the animals could turn around several times by using the head, one forepaw and one hindpaw (Fig. 3f).

After having their nest box uncovered the shrews aged 14 days first fled quickly (escape behaviour) and hid under the moss but could not return unaided. If they were near each other they collected and became immobile, huddled together. They were brought separately to the nest by their mother. Two or three days later the locomotor and orienting abilities were so well developed that the animals left alone near the nest could find their way to it, although their mother still retrieved them.

At this age the shrews placed in an empty cage sought a hiding place. They crept, for instance, under papers, clouts or a curled human hand lying on the floor of the cage, huddling together there.

Despite already well developed motor skills 17-day old shrews lost balance easily while crawling and toppled over. They could crawl quite quickly, but spread the paws widely and dragged their bellies. Only on day 19 did they elevate the trunk above the surface. (After opening of eyes the animals stopped turning around).

Young shrews left the nest at the earliest, on day 23 (mean age: $23.9 \pm 0.8$ days, Fig. 4). Initially they left the nest box for a few seconds 
but never went far from it. When frightened they immediately hid under the moss or escaped quickly to the nest. After two or three days the young knew the cages very well (mothers with young were kept in several cages connected by rubber tubes), and their apparent shyness gave way to curiosity. They were not afraid to climb the new objects (or human hand) placed in the cages.

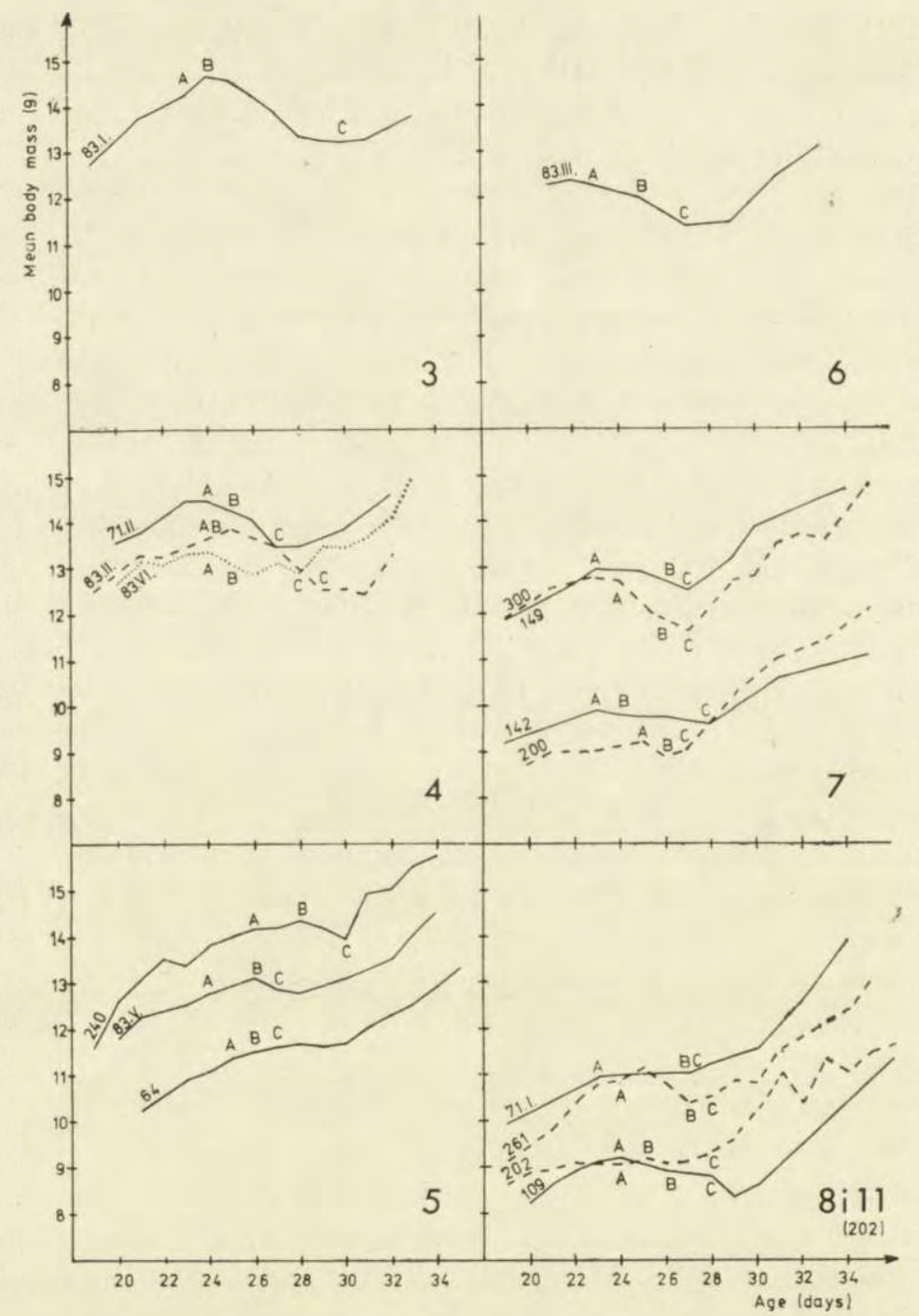

Fig. 4. Mean body mass gain curves in $N$. fodiens from different-sized litters upon nest leaving. Litter number is at the beginning of each curve. Lower right corner figures show the number of animals in litter. A - nest leaving, B - first observed milk drinking from bowls, C - first eating of solid food. 


\subsubsection{Vocal Abilities}

Squeaks by young shrews were first heard on the day 11, when their appearance was studied (in only one litter). Young of other litters were heard first squeaking on days 13-14, but most frequently at the end of the third week of life. Squeakings were sharp, and short. Young shrews squeaked when they were put by man inta or taken out of the nest and during handling ("protest" calls). From day 14 a soft squeaking was sporadically heard when mother entered the nest.

A loud squeak resembling prolonged hissing was heard for the first time on day 21 , from a young animal being pushed by man into the nest box through its narrow entrance. On the following days the young shrews hissed more and more frequently when they were roughly handled. In adults this hissing sound was uttered during accidental, brief encounters with alien conspecifics, and it seems to serve for warning and deterring ("threating" calls).

At the age of 22 days disturbed shrews sharply chirped then usually hissed. These "shrieks" were uttered by adults during longer and more aggressive encounters between strange conspecifics (e.g. when a stranger tried to enter the nest of another animal or during prolonged chasing). In young shrews, up to the end of the 6 th week of life these shrieks (chirping with hissing) were very rarely heard, and in relation to adults these shrieks were more brief (chirping, in particular) and more subtle. Young shrews molested by siblings or man emitted, most frequently, only short squeaks. When aggressiveness by young animals increased significantly during weeks $7-8$ (Michalak, in press) chirping and hissing was more frequently heard from young ones.

Up to age 60 days (further observations are not available) the young were not heard to emit another type of sound characteristically uttered by adults (a monotonous, piercing, and long-lasting chirping, similar to rattling) indicating a very high degree of aggressive excitement of the animals, usually preceding fights.

\subsubsection{Grooming}

Mothers usually devoured excreta of the young nestlings. Excreta of the older animals were left outside the nest and the mothers never ate them. However, on day 29 a female was seen to eat the excreta of her young while she was licking its underbelly.

The females licked the anal area of young most frequently while they were sucking, less often while they were asleep. The oldest animal was 

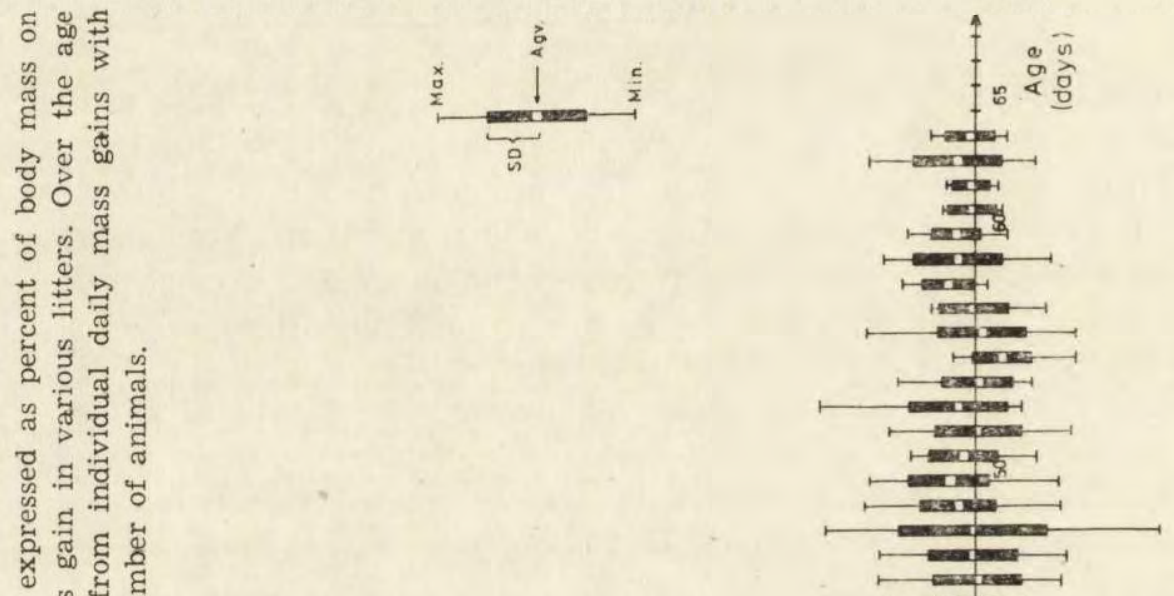

안

น )

ङे है

¿ व

乙

ઘลิ ส

중 की

i 1

嵌 苍苋

용 ฮี ฮี

$\rightarrow$ s

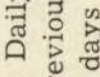

的

运

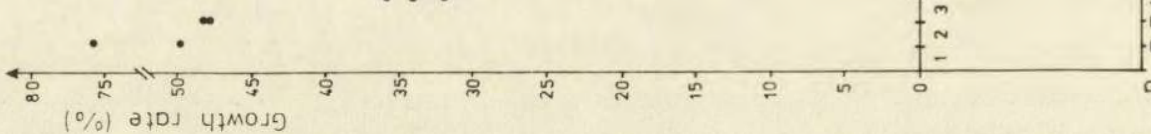


seen to have its hindquarters licked by its mother at day 35 (this young had been eating solid food for a week).

After leaving the nest the young shrews were seen to scratch various regions of the body (no data were available on this behaviour during the in-nest development phase). Young shrews were seen, for the first time, on day 32, licking their anal area. Self-licking and scratching occurred most frequently after feeding and defecation by young. Young shrews scratched with hindpaws only. Face-washing by 60 days was not seen.

\subsubsection{Weaning}

Young shrews first drank milk from bowls at day 24 (mean age: $25.4 \pm 1.0$ days) (Fig. 4). Initially they crept into milk bowls, dipped their entire muzzles, shook themselves, and fled. They were seen also to lick milk from the fur of another shrew or from themselves. After two days they daily drank $20-30 \mathrm{ml}$ each.

On the 27th day of life, when their teeth were already sharp, some young ate minced meat (mean age: $27.8 \pm 1.0$ days) (Fig. 4 ). Before then faeces of the young were green; after initiating consumption of solid food it gradually assumed a dark brown colour. Simultaneously young animals mouthed but did not eat live meal worms larvae (Tenebrio molitor). They readily ate these larvae torn to shreds by the mother, however frequently taking pieces of them directly from her mouth. The number of animals in a litter had no effect on the age at which the young first drank milk from bowls and ate solid food (Fig. 4).

Duration of the lactation period was determined by observing sucking and the appearance of the nipples of the females (Plate IX, Photo A; see also Michalak, 1983). Young in 7 litters staying with their mothers to 50 days sucked to day 38 , on average (range: $34-41$ days). Ten other litters were isolated from their mothers at 28 to 35 days, when they were still sucking. This isolation from the still lactating mothers had no unfavourable effect on the condition of the young shrews. The family bonds persisted up to about 50 days of age (see Michalak, 1983).

\subsection{Body Mass Changes}

The highest rate of relative mass gain (expressed as percent of body mass on the preceding day) was observed during the first two weeks of life (Fig. 5). On the first day of life it was even over $50 \%$ and on second day near $50 \%$ (Table 2). On the three following days it ranged from $34 \%$ to $24 \%$. In most litters mass gain rates over $10 \%$ were observed up 


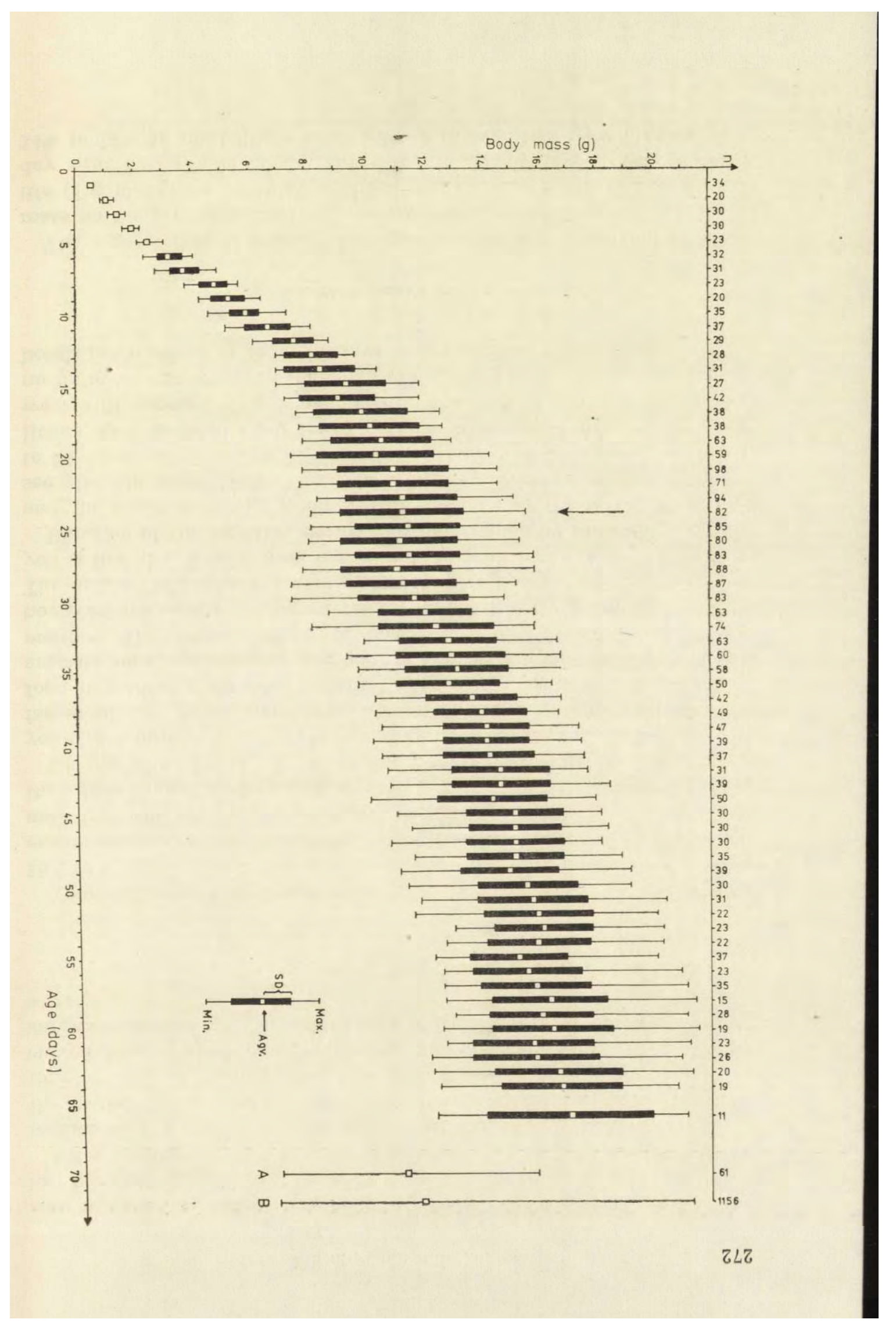


to day 10 (Fig. 5). Young water shrews experienced fivefold mass gain, by day 6 , and tenfold at the age of $10-11$ days (Fig. 6).

Several days before leaving of the nest, mass gain rate decreased appreciably (Fig. 5). Upon leaving the nest, mean body mass of 98 young from 16 litters was $11.5 \mathrm{~g}$. This means that at the end of the nest phase of life the young were 19.4 times heavier than at birth.

After leaving the nest body mass fell or, at least, its gain was inhibited (Figs 4 and 6). Only 5 out of 95 young shrews showed no reduction in mass gain after leaving the nest. This reduction most frequently appeared on the day of nest leaving. Sometimes, however, body mass increased further for one or two days and only then it decreased (Fig. 4).

Table 2

Relative mass gain by young $N$. fodiens during the first two days of life expressed as percent of body mass at previous weighting.

\begin{tabular}{lccc}
\hline Litter No. & $\begin{array}{c}\text { Age during } \\
\text { measurements } \\
(\mathrm{h})\end{array}$ & $\begin{array}{c}\text { Time of } \\
\text { mass gain } \\
(\mathrm{h})\end{array}$ & $\begin{array}{c}\text { Relative } \\
\text { mass gain } \\
(\%)\end{array}$ \\
\hline 308 & $1(9)-24(33)$ & 24 & 50.0 \\
83 I & $13-27$ & 14 & 22.5 \\
300 & $20-44$ & 24 & 76.3 \\
83 I & $27-51$ & 24 & 48.6 \\
308 & $24(33)-48(57)$ & 24 & 48.2 \\
\hline
\end{tabular}

Mass gain returned when young shrews began eating solid food (Fig. 4). The mean time between the day of beginning of body mass fall (or inhibition) and the day when animals reached again body mass equal to that before reduction was $5.4 \pm 1.9$ days (range: $0-12$ days, $n=92$ ). The coefficient of variation (CV) of this feature within various litters ranged from 6.7 to $79.5 \%$, and calculated for all the observed shrews it was $49.6 \%$. No correlation was found between the litter size and the time of body mass reduction $(r=0.16, p>0.1)$ or the value of its $\mathrm{CV}$ $(r=0.02, p>0.1)$ in individual litters.

Mean mass gain rate after achieving of nutritional independence reached its highest value on day $30(5 \%)$, thereafter being maintained below $4 \%$ and never over $2 \%$ from day 40 onwards (Fig. 5).

Fig. 6. Mean $( \pm \mathrm{SD})$, minimal and maximal body mass of $N$. fodiens on successive days of life. Up to the fifth day of life not all young were weighed individually. Mean body mass was calculated for all weighed animals, while the minimal and maximal values were measured only in 8-12 individuals. A, B - mean, minimal and maximal body mass of wild caught subadults in May and first half of June (A) and those caught throughout the whole year (B). Arrow in the graph shows the mean age of the young upon leaving the nest. $n$ - number of animals. 
Under our laboratory conditions the young shrews gained fat, which could be palpated through the skin e.g. on the neck. An example of fat gaining may be the rise in the body mass of shrews weighed up to the age of 4 months (Table 3, compare data with those for free-ranging subadults, Fig. 6).

Table 3

Body mass of young $N$. fodiens aged 2 to 4 months (litter no. 18).

\begin{tabular}{rcccccccc}
\hline \multirow{2}{*}{$\begin{array}{c}\text { Age } \\
\text { (days) }\end{array}$} & \multicolumn{9}{c}{ Body } & \multicolumn{9}{c}{ mass } & \multicolumn{6}{c}{ individuals in a litter $(\mathrm{g})$} & \multirow{2}{*}{$\begin{array}{c}\text { Mean } \\
\text { mass (g) }\end{array}$} \\
\cline { 2 - 8 } & 1 & 2 & 3 & 4 & 5 & 6 & \\
\hline 57 & 15.2 & 17.7 & 20.7 & 16.7 & 16.4 & 17.2 & 17.5 \\
70 & 16.0 & 18.1 & 20.7 & 17.1 & 17.4 & 17.1 & 17.7 \\
80 & 16.3 & 19.0 & 20.8 & 17.4 & 17.4 & 17.4 & 18.1 \\
91 & 17.1 & 19.7 & 21.1 & 17.3 & 18.1 & 17.5 & 18.5 \\
100 & 18.0 & 21.1 & 20.9 & 19.0 & - & 19.3 & 19.7 \\
110 & 20.2 & 23.9 & - & 21.0 & - & 20.7 & 21.5 \\
131 & 22.7 & 22.9 & - & 20.0 & - & 20.2 & 21.5 \\
\hline
\end{tabular}

3.5. Relationship Between Body Mass and Litter Size

Body mass of young in litters of varying size were compared at age three weeks (Table 4). Coefficient of variation of body mass was not correlated with the number of young in a litter $(r=0.07, p>0.1)$ (Table 4).

Table 4

Body mass of $N$. fodiens aged 21 days.

\begin{tabular}{|c|c|c|c|c|c|c|c|c|}
\hline \multirow{2}{*}{$\begin{array}{l}\text { No. of } \\
\text { young } \\
\text { in } \\
\text { litter }\end{array}$} & \multirow[t]{2}{*}{$\begin{array}{l}\text { Litter } \\
\text { No. }\end{array}$} & \multirow[t]{2}{*}{ Avg. } & \multirow[t]{2}{*}{ SD } & \multirow[t]{2}{*}{ Min.-Max. } & \multirow{2}{*}{$\mathrm{CV}$} & \multicolumn{3}{|c|}{$\begin{array}{l}\text { Mean for litters } \\
\text { of the same number } \\
\text { of young }\end{array}$} \\
\hline & & & & & & Avg. & $\mathrm{SD}$ & $\mathrm{CV}$ \\
\hline 1 & 16 & & & 15.6 & & & & \\
\hline 3 & $83 \mathrm{I}$ & 13.79 & 0.59 & $13.2-14.4$ & 4.28 & & & \\
\hline 4 & $83 \mathrm{II}$ & 13.30 & 0.79 & $12.2-14.0$ & 5.94 & & & \\
\hline 4 & $83 \mathrm{VI}$ & 13.18 & 9.47 & $12.6-13.7$ & 3.57 & 13.43 & 0.67 & 4.99 \\
\hline 4 & $71 \mathrm{II}$ & 13.83 & 0.68 & $13.2-14.6$ & 4.92 & & & \\
\hline 5 & 64 & 10.22 & 1.22 & $9.1-12.0$ & 11.94 & & & \\
\hline 5 & $83 \mathrm{~V}$ & 12.27 & 0.50 & $11.6-12.9$ & 4.07 & 11.77 & 1.49 & 12.66 \\
\hline 5 & 240 & 13.10 & 0.70 & $12.5-14.0$ & 5.34 & & & \\
\hline 6 & $83 \mathrm{III}$ & 12.32 & 0.74 & $11.1-13.1$ & 6.01 & & & \\
\hline 7 & 142 & 9.56 & 0.58 & $8.8-10.6$ & 6.07 & & & \\
\hline 7 & 149 & 12.43 & 0.48 & $11.9-13.0$ & 3.86 & 10.88 & 1.74 & 16.00 \\
\hline 7 & 200 & 8.97 & 0.47 & $8.4-9.8$ & 5.24 & & & \\
\hline 7 & 300 & 12.52 & 0.83 & $11.2-13.6$ & 6.63 & & & \\
\hline 8 & $71 \mathrm{I}$ & 10.47 & 0.65 & $9.3-11.4$ & 6.21 & & & \\
\hline 8 & 109 & 8.65 & 0.64 & $7.9-9.7$ & 7.40 & 9.71 & 0.97 & 9.99 \\
\hline 8 & 261 & 10.03 & 0.45 & $9.4-10.7$ & 4.49 & & & \\
\hline 11 & 202 & 8.95 & 0.47 & $8.4-9.8$ & 5.25 & & & \\
\hline $\begin{array}{l}\text { Total } \\
(n=99)\end{array}$ & & 11.04 & 1.93 & $7.9-15.6$ & 17.45 & & & \\
\hline
\end{tabular}


Mean body mass however decreased with increased litter size $(r=-0.84$, $p<0.001, y=0.73 x+16.02$ ) (Fig. 4 and Table 4). The effect of the litter size on the mean body mass of young was generally detectable almost throughout the whole nesting period.

The differences in the mean body mass of young shrews from large and small litters were maintained also after the nesting period. Similarly, within the individual litters the strongest and the weakest animals remained frequently, strong or weak after achieving of full nutritional independence. Thus the condition achieved by young during the nest development influenced significantly their further development (at least up to the age of 50 days, when animals were kept together in common, cages).

\subsection{Subadult Age Body Mass}

Body mass of captive born young water shrews was compared with that of wild-caught subadults at the beginning of the reproductive season, that is in May and in the first half of June (Fig. 6). This comparison shows that: (1) $38 \%$ of the captive shrews by day 11 and all of them by day 15 reached or exceeded the lower range of the subadult body mass, (2) subadult mean body mass was attained by $7 \%$ of the young on day $16,(3)$ by day 24 the mean body mass of captive young approximately equalled that of wild subadults $(11.3 \mathrm{~g}$ and $11.4 \mathrm{~g}$ respectively), (4) the upper range of body mass of subadults was exceeded by some $(4.7 \%$, young shrews on day 33 , and (5) the mean body mass of captive shrews aged over 50 days fluctuated within the range of the maximal body masses of subadults.

\section{DISCUSSION}

\subsection{Locomotion, Vocalization, Nest Leaving and Feeding}

Spinning ("top") movements by young Neomys fodiens on days $6-7$ have been previously documented by Vogel (1972a) and Köhler (1984). Young shrews presently observed tried to move in this way on the 2nd day, full spinning movements performed on days $4-5$. Accurate observation of locomotion during the first days is possible only immediately after removal from the nest, since the young become sluggish very rapidly. This may account for differences in observegd development.

The first squeaks of the young water shrews were heard by Köhler (1984) on the 13th day of their life, when an adult animal entered the nest. Vogel (1972a) stated that the young animals first uttered sounds 
on the 14th day of life. I first heard squeaks of young $N$. fodiens on day 11 , but young in most litters began squeaking after the age of two weeks.

Köhler's (1984) young shrews first left the nest two days earlier than was noted in this study (23-25 days). Köhler (1984) first saw young shrews drinking on day after they were interested in solid food. He stated, moreover, that young shrews were very rarely seen drinking before day 42. My observations suggest, however, a reverse behaviour of the animals. They were first observed drinking, several days before they began eating solid food. They often drank after leaving the nest. Köhler (1984) gave his animals water, but mine had milk only and this may have accelerated their drinking behaviour.

\subsection{Weaning}

Published data on the time of weaning in Neomys fodiens vary considerably (Table 5), chiefly because of different weaning determination and definition. This problem is connected with use of three terms: weaning, nutritional self-dependence and lactation termination. Crowcroft's (1957) determination of weaning in $N$. fodiens, Sorex araneus and $S$. minutus by observation of first solid food consumption was contested by Vlasák (1973). Both authors used the term "weaning" in the meaning of lactation termination. Vlasák (1973) separated exactly the data on the first intake of solid food from the time of lactation termination in Crocidura suaveolens (Pallas, 1811) (Table 5). I agree with him since interest in solid food by young $N$. fodiens shows only potential nutritional selfdependence, not complete independence.

Vogel (1972a) indirectly determined weaning time in $N$. fodiens interpreting the course of body mass gain curve. Body mass fall $(n=2$ !) between days 26 and 28 was interpreted as indicating that animals began self-dependent feeding, and increase in body mass between days 28 and 29 was regarded as an evidence of lactation termination (=weaning time). In a similar way Vogel (1970) determined the weaning time in Suncus etruscus Savi, 1832 (at 20-21 days) but accepting decrease in body mass as an evidence of the end of lactation. Such indirect estimation of lactation termination, not supported by any observations of the behaviour of animals, seems to be unacceptable.

Vogel's $(1970,1972 a)$ methodology is in some degree analogous with that of King et.al. (1963), who determined weaning age as the age at which the young animals maintain or increase their body mass during 24-hour separation from their mother. These authors stressed also that weaning is a gradual process resulting from the ability of young to take 
another food than mother's milk and from unwillingness of mothers to feed them. A controversy exists, however, between the understanding of the word "weaning" by King et al. (1963) and their determination of weaning time. The method of King et al. (1963) can indicate only one day in the life of young animals, while, if weaning is to be regarded as a prolonged process, it should cover several days.

This method seems to be a good way for determination of the age at which captive young animals achieve full optimal nutritional self-dependence. Excess food available under laboratory condition, but presumably not to wild shrews, permits the former to survive at younger age. If the method of King et al. (1963) could be used in study of wild animals it could serve in determinating of the age of full self-dependence in the search for food.

The method of King et al. (1963) was used by Dryden (1968) in determinating nutritional self-dependence by Suncus murinus Linnaeus, 1766 (17th day of life). Since, however, 20-day-old shrews still nursed weaning was assumed accomplished by $17-20$ days. Dryden (1968) considered weaning as a several-days-long process in the development of the young shrews.

Köhler (1984) separated the first solid food ingestion by the young $N$. fodiens (days $24-27$ ) from cessation of nursing by the mother ( 36 day) by direct observation of animal behaviour and faeces colour change. (Faeces were still green in two-thirds of the animals still sucking by day 35). Köhler's (1984) data agree approximately with of this study.

Because of confusion in describing or determining weaning age I propose that "weaning" be used to indicate gradual processes of development during which young shrews become independent of mother's milk and attain full nutritional self-dependence. This begins when young are potentially nutritionally self-dependent (observation of first eating solid food and coloration of feaces), and ends when sucking is completely abandoned (observation of sucking behaviour of young animals, appearance of mother's nipples and colour of feaces of young).

The end of lactation in $N$. fodiens accepted in the present study (day 38 ), may be an overestimation in relation to duration of lactation in wild animals. Prolonged lactation by captive $N$. fodiens may be due to limited cages area, inability of the mother to escape, low aggressiveness of the female against her offspring (Michalak, in press) and application of extend the sucking stimulus. Evidence that normal lactation duration in this species is 5 weeks is provided by the observation of infant-maternal behaviour: (1) females do not avoid contacts with their young before day 35 of lactation (Michalak, in press), (2) a "high need" for and intensity of sucking was observed experimentally in the young 


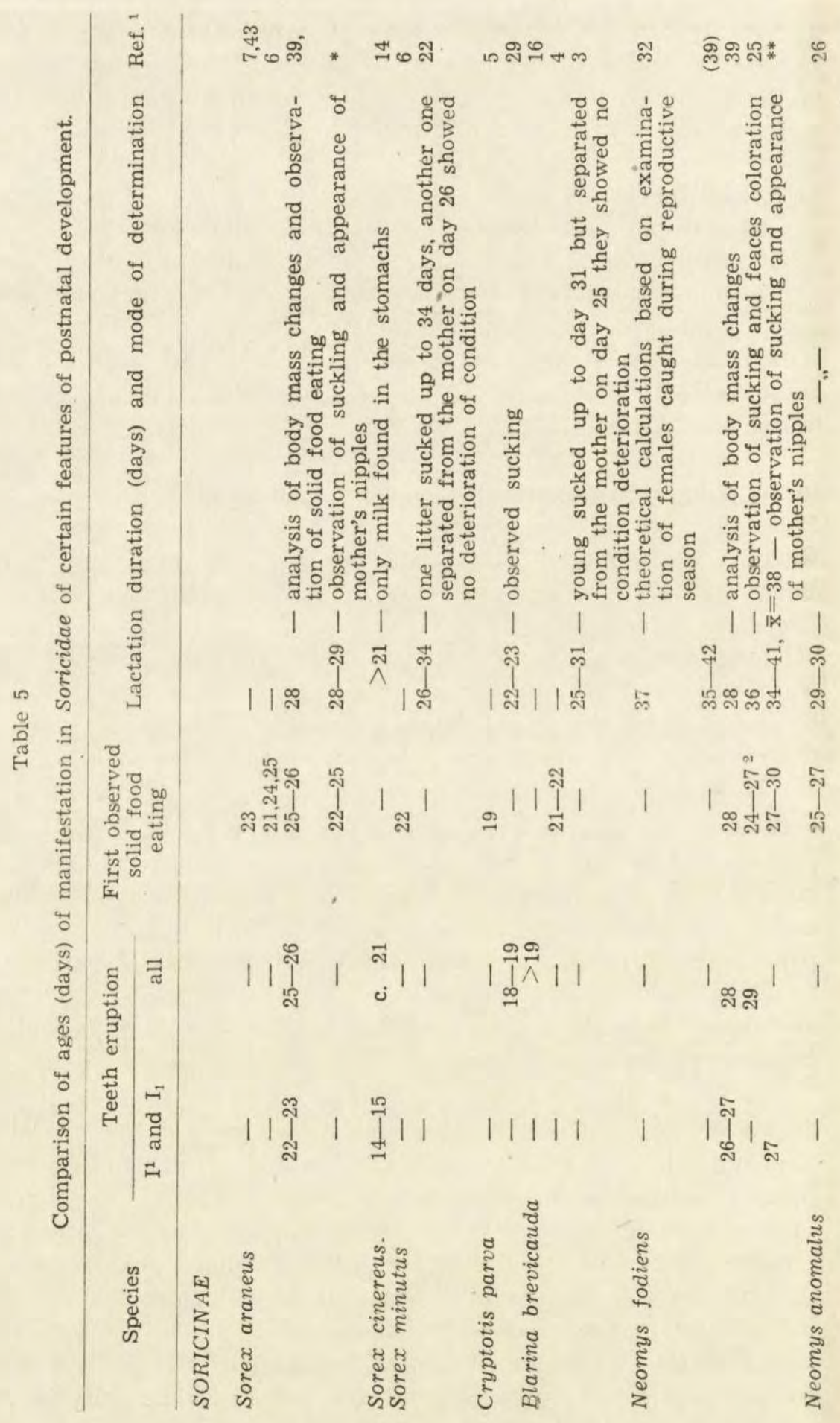




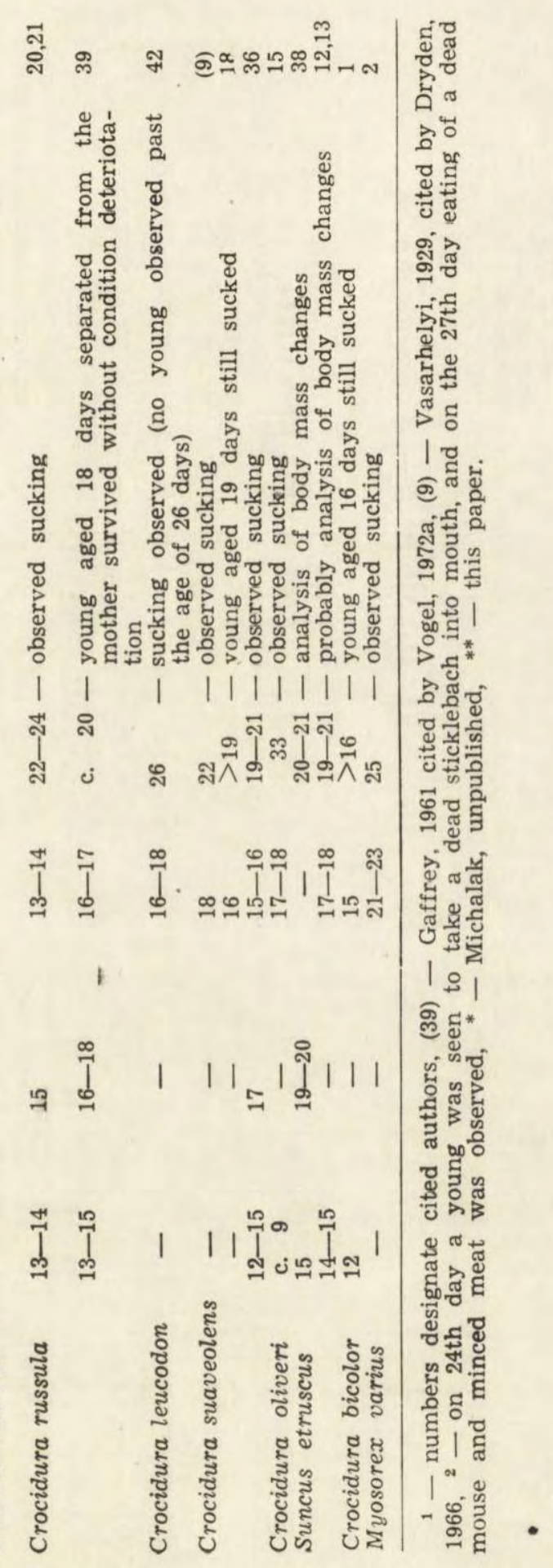




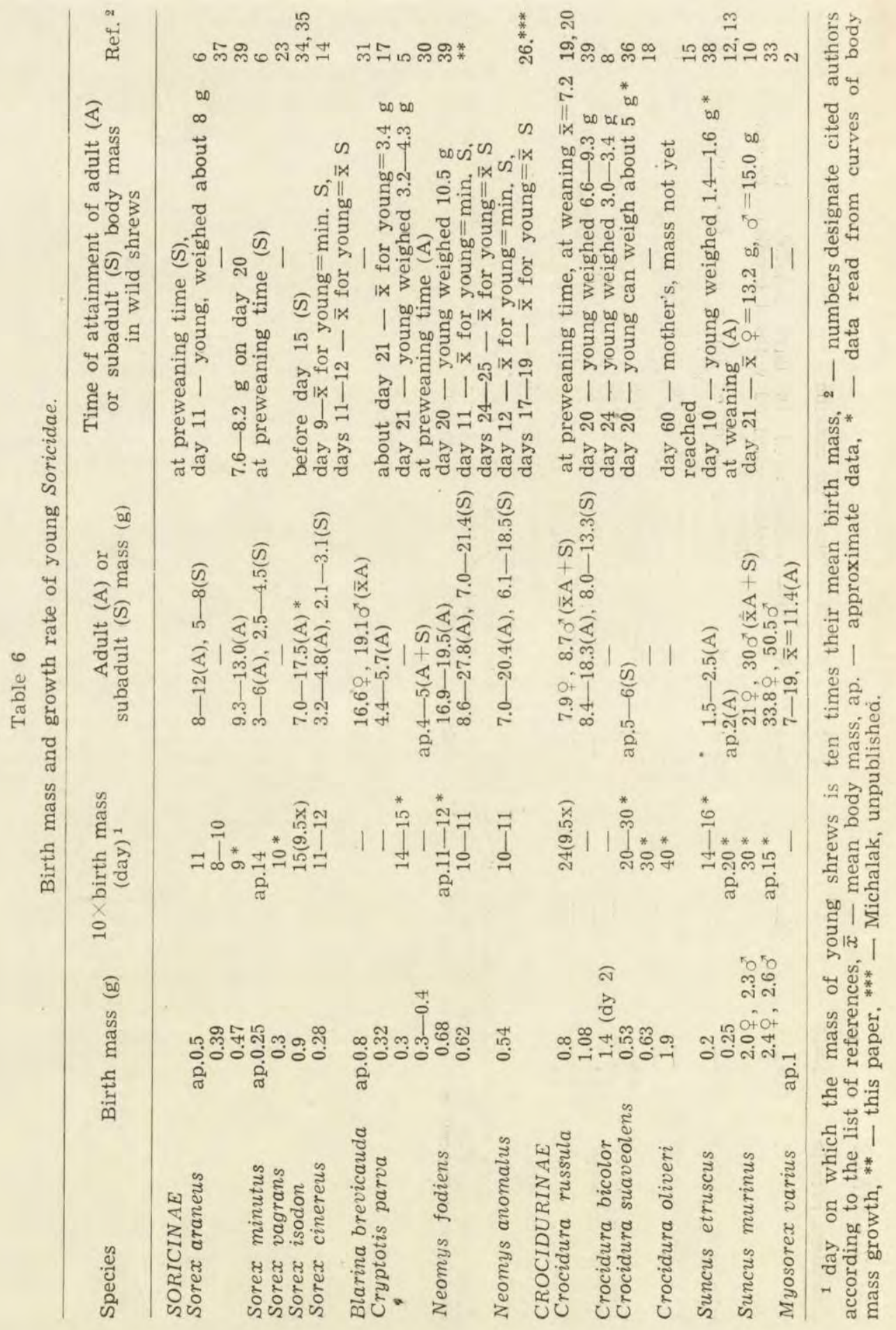


animals up to 35 days (Michalak, in prep.), (3) nonpregnant suckling $N$. fodiens separated from their 28-30 day-old young experienced oestrus only 35-39 days after the preceding one (Michalak, 1983).

The beginning of solid food consumption by the young $N$. fodiens does not coincide with the end of lactation. The difference between the time of onset of these developmental phases in different shrew species may range from several days to about two weeks (Table 5). Despite Vogel's (1972a) interpretation, no strict sequence of developmental phases (eruption of all teeth, taking of solid food, lactation termination) holds for shrews studied to date.

Since gestation in $N$. fodiens lasts 20 days (Michalak, 1983), it is possible to calculate that females conceiving at the first postpartum oestrus should deliver a litter when the preceding one had to be fed exclusively with milk for one week, and two weeks before termination of sucking by preceding litter. It seems that prolongation of pregnancy must occur in $N$. fodiens females suckling despite pregnancy. Vogel (1981) observed prolongation of 20-day pregnancy by 7 days in Sorex araneus fertilized during postpartum oestrus. Pregnancy prolongation by suckling $N$. fodiens fertilized during the postpartum oestrus remains however an open question.

\subsection{Body Mass Gain}

As in $N$. fodiens a high mass gain rate was observed in a closely related species, Neomys anomalus Cabrera, 1907 (Michalak, 1982). Day 10-11 young of both species weighed ten times their respective birth masses, mean body mass upon leaving the nest of young $N$. anomalus was 18.1 times mean birth mass (Michalak, unpublished). This high mass gain rate of nestling Neomys is in some degree correlated with very low birth mass in relation to adult mass.

Published birth masses of other Soricinae species are 15-25 times lower than adult body mass (Table 6). In most species of this subfamily a tenfold rise of birth mass occurs at the age of 10-14 days (Table 6). One exception is Sorex isodon Turov, 1924 (Skarén, 1979, 1982).

Birth mass of Crocidurinae is about ten times lower than adult mass and the rate of mass gain is also lower (Table 6). Only young Suncus etruscus during the first days of life gain mass as rapidly as young Soricinae, since a tenfold birth mass is reached by these animals at the age of 14-16 days (Vogel, 1970). Exceptionally large newborns and slow mass gain rate were observed in Crocidura bicolor Bocage, 1889 (Dippenaar, 1979). If age determination of wild caught young Crocidura bicolor is valid, this species would have the largest newborns in relation to adult mass of all Soricidae studied. 
Body mass loss by young $N$. fodiens after nest leaving may be caused by two factors, that is a sharp increase in locomotor activity and the failure of mother's milk to cover their increasing nutritional requirements. Since young shrews immediately after leaving the nest avidly drank milk from bowls, this could either reduce the rate of mass loss or delay the beginning of meat eating compared with the case of meat being the only available food besides the mother's milk.
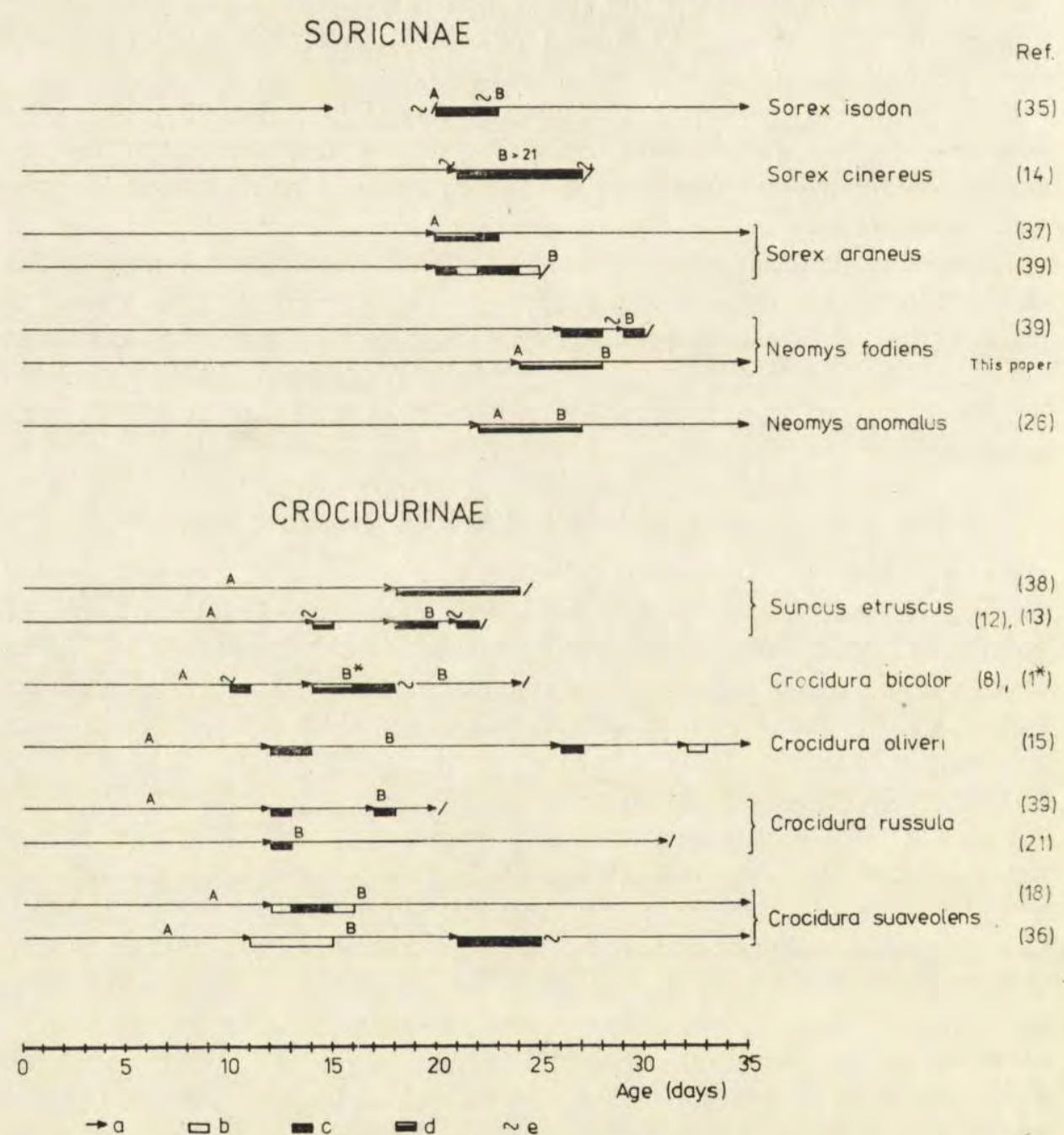

Fig. 7. Mass gain in certain Soricidae species. Ref. - means the reference number.

A - nest leaving (in case of Crocidurinae - young leave the nest "in caravan"),

B - first eating of solid food, a - body mass gain, b - arrest of mass gain, c - mass loss, d - inhibited mass gain or loss, e - approximate data. 
The same transient mass loss in the preweaning period is also observed in other Soricidae species, and in young Crocidurinae this mass loss or transient arrest of mass gain occurred earlier than in young Soricinae (Fig. 7). The cause of this difference is probably a different pattern of locomotor ability development and food acquiring activity in the nestlings from both subfamilies.

Young Soricinae leave the nest only after the age of 20 days (after opening of eyes), and begin eating solid food at the age of $3-4$ weeks (Table 5). The time interval between nest leaving and eating of the first meat food is only $2-5$ days. It may be assumed that both factors which could cause weight loss (locomotor activity and food deficiency) occur at nearly the same time in young Soricinae. Thus decreased mass gain coincides approximately with nest leaving, while its return indicates the beginning of solid food eating (Fig. 7).

Young Crocidurinae first leave the nest forming a "caravan" at 5-10 days (still blind). They first eat solid food at $2-3$ weeks (Table 5). The time interval between locomotion and ingestion of solid food is $7-11$ days. The development of locomotor skill in young Crocidurinae is gradual, not so sudden as in young Soricinae. The analysis of body mass changes cannot be used for the determination of the time of nest leaving or meat eating by young Crocidurinae (Fig. 7).

\subsection{Time of Achieving of Subadult Body Mass}

Achievement of subadult body mass by preweaning $N$. fodiens, probably, characterizes the subfamily Soricinae (Table 7). Only three species of Crocidurinae have been studied sufficiently to demonstrate that subadult body mass is attained prior to the termination of lactation: Suncus etruscus (Fons, 1973, 1976; Vogel, 1970), Crocidura russula (Hellwing, 1973a, b; Vogel, 1972a), and Crocidura suaveolens (Vlasák, 1972) (Table 7).

Forsyth (1976) hypothesized that nestling Old World and North American Soricinae experience excessive mass gain in relation to stable subadult mass. Certain doubts arrose about this hypothesis, when respective data (e.g. those by Johnston and Rudd, 1957; Conaway, 1958; Vlasák, 1973; Forsyth, 1976; Skarén, 1982) were reviewed in some details. These authors compared maximal body mass of young shrews at preweaning, weaning or postweaning age with that of subadults living under varied (laboratory or wild) conditions. Thus excess body mass was observed not only in nestling but also in older shrews. Except this, body mass of young Soricinae was related only to that of subadults mass at strictly determined age. 
In nestling $N$. fodiens described in this paper no excess of body mass was observed in relation to that of subadults caught at the beginning of the reproductive season or throughout the whole year and in relation to captive subadults. After the age of 30 days the mean body mass of young captive water shrews exceeded that of wild caught subadults. However, uncritical comparison of the body mass of the captive animals and wild ones might lead to erroneous conclusions. The exces: of body mass in the captive shrews after reaching nutritional self-dependence might be due only to greater availability of food in captivity, which was offered ad libitum. At any rate, the mean body mass of young water shrews over 50 days old, approached the upper range of mass variability of wild subadults by accumulation of more adipose tissue in captive animals.

Acknowledgements: I wish to express my gratitude to Professors $\mathrm{Z}$. Pucek and M. Gębczyński for their critical reading of earlier draft of this paper and editorial comments, and to Dr. Gilbert L. Dryden (Slippery Rock State College) for his criticism and linguistic corrections. I thank S. Bogdańska for taking care of captive animals and L. Szuma for her excellent typing.

\section{REFERENCES}

1. Ansel W. F. H., 1964; Captivity behaviour and post-natal development of the shrew Crocidura bicolor. Proc. Zool. Soc. Lond., 142: 123-127.

2. Baxter D. M. \& Lloyd N. V., 1980: Notes on the reproduction and postnatal development of the forest shrew. Acta theriol., 25: 31-38.

3. Blus L. J. \& Johnston D. A., 1969: Adoption of a nestling house mouse by a female short tailed shrew. Am. Mid. Nat., 81: 583-584.

4. Blus L. J., 1971: Reproduction and survival of short-tailed shrews (Blarina brevicauda) in captivity. Lab. Anim. Sci., 21: 884-891.

5. Conaway C. H., 1958: Maintenance, reproduction and growth of the least shrew in captivity. J. Mammal., 39: 507-512.

6. Crowcroft P., 1957: The life of shrew. Max Reinhardt: 1-166. London.

7. Dehnel A., 1952: Biologia rozmnażania ryjówki $S$. araneus L. w warunkach laboratoryjnych. Annls Univ. M. Curie-Sklodowska, C, 6 (1951), 11: 359-376.

8. Dippenaar N. J., 1979: Notes on the early post-natal development and behaviour of the tiny musk shrew Crocidura bicolor Bocage, 1889 (Insectivora: Soricidae). Mammalia, 43: 83-91.

9. Dryden G. L., 1966: Reproduction in Suncus murinus, Doct. diss. (manuscript).

10. Dryden G. L., 1968: Growth and development of Suncus murinus in captivity on Guam. J. Mammal., 49: 51-62.

11. Fedyk S. \& Borowski S., 1980: Colour variants in the Białowieża population of European water shrew. Acta theriol., 25: 3-24.

12. Fons R., 1973: Modalités de la reproduction et développement postnatal en captivité Suncus etruscus (Savi, 1822). Mammalia, 37: 288-325.

13. Fons R., 1976: Contribution à la connaissance Pachyure étrusque Suncus etruscus (Savi, 1822) (Mammifère Soricidae). Vie Milieu, 21(1C): 209-218 
14. Forsyth D. J., 1976: A field study of growth and development of nestling masked shrews (Sorex cinereus). J. Mammal., 57: 108-121.

15. Grünwald A, von \& Möhres F. P., 1974: Beobachtungen zur Jugendentwicklung und Karawanbildung bei Weisszahnspitzmäusen (Soricidae-Crocidurinae). Z. Säugetierkunde, 39: $321-336$.

16. Hamilton W. J. Jr., 1929: Breeding habits of the short-tailed shrew, Blarina brevicauda. J. Mammal., 10: 125-134.

17. Hamilton W. J. R., 1944: The biology of short-tailed shrew, Cryptotis parva. J. Mammal., 25: 1-7.

18. Hanzák J., 1966: Vývoj mládat bělozubky sědé Crocidura suaveolens (Pallas) 1822. Lynx, 6: 67-74.

19. Hellwing S., 1971: Maintenance and reproduction in the white-toothed shrew, Crocidura russula monacha Thomas, in captivity Z. Säugetierkunde, 36: 103-113 .

20. Hellwing S., 1973a: Husbandry and breeding of white-toothed shrews in the Research Zoo of the Tel-Aviv University. [In: "International Zoo Yearbook", N. Duplaix-Hall, ed.] 13: 127-134. London.

21. Hellwing S., 1973b: The postnatal development of the white-toothed shrew Crocidura russula monacha in captivity. Z. Säugetierkunde, 38: 257-270.

22. Hutterer R., 1976: Beobachtungen zur Geburt und Jugendentwicklung der Zwergspitzmaus Sorex minutus L, (Soricidae-Insectivora). Z. Säugetierkunde, 41: $1-22$.

23. Johnston R. F. \& Rudd R. L., 1957: Breeding of the salt marsh shrew. J. Mammal., 38: 157-163.

24. King J. A., Deshaines J. C. \& Webster R., 1963: Age of weaning in two subspecies of deer mice. Science, 139: 483-485.

25. Köhler D., 1984: Zum Pflegeverhalten and Verhaltensontogenese von Neomys fodiens (Insectivora: Soricidae). Zool. Anz., 213: 275-290.

26. Michalak I., 1982: Reproduction and behaviour of the Mediterranean water shrew under laboratory conditions. Säugetierkundl. Mitt., München, 30: 307-310 .

27. Michalak I., 1983: Reproduction, maternal and social behaviour of the European water shrew under laboratory conditions. Acta theriol., 28: 3-24.

28. Michalak I., (in press): Behaviour of young Neomys fodiens in captivity. Acta theriol.

29. Mock O. B, \& Conaway C. H., 1976: Reproduction of least shrew (Cryptotis parva) in captivity. [In: "The laboratory animal in the study of reproduction" 6th ICLA Symp. Thessaloniki 1975, Th. Antikatzides, S. Erischen, A. Spiegel, eds.] G. Fischer Verlag: 59-71. Stuttgart, New York.

30. Mock O. B., 1982: The least shrew (Cryptotis parva) as a laboratory animal. Lab. Anim. Sci., 32: 177-179.

31. Pearson O. P., 1944: Reproduction in the shrew (Blarina brevicauda Say). Am. J. Anat., 75: $39-83$.

32. Price M., 1953: The reproductive cycle of the water shrew, Neomys fodiens bicolor Shaw. Proc. Zool. Soc. Lond., 123: 599-621.

33. Shigehara N., 1980: Epiphyseal union and tooth eruption of the Ryukyu house shrew, Suncus murinus, in captivity. J. Mamm. Soc. Japan, 12: 151-159.

34. Skarén U., 1979: Variation, breeding and moulting in Sorex isodon Turov in Finland. Acta Zool. Fennica, 159: 1-30.

35. Skarén U., 1982: Intraspecific aggression and postnatal development in the shrew Sorex isodon Turov. Ann. Zool. Fennici, 19: 87-91. 
36. Vlasák P., 1972: The biology of reproduction and post-natal development of Crocidura suaveolens Pallas, 1811 under laboratory conditions. Acta Univ. Carol., Biol., 3 (1970): 207-292.

37. Vlasák P., 1973: Vergleich der postnatalen Entwicklung der Arten Sorex araneus L. und Crocidura suaveolens (Pall.) mit Bemerkungen zur Methodik der Laborzucht (Insectivora: Soricidae). Vestn. Cesk. Spol. Zool., 37: 173-185.

38. Vogel P., 1970: Biologische Beobachtungen an Etruskerspitzmäusen (Suncus etruscus Savi, 1832). Z. Säugetierkunde, 35: 173-185.

39. Vogel P., 1972a: Vergleichende Untersuchung zum Ontogenesemodus einheimischer Soriciden (Crocidura russula, Sorex araneus and Neomys fodiens). Rev. suisse Zool., 79: 1201-1332.

40. Vogel P., 1972b: Beitrag zur Fortpflanzungsbiologie der Gattungen Sorex, Neomys und Crocidura (Soricidae). Verh. naturf. Ges. Basel, 82: 165-192.

41. Vogel P., 1981: Occurrence and interpretation of delayed implantation in insectivores. J. Reprod. Fert., 29: 51-60.

42. Wahlström A., 1929: Beitrag zur Biologie von Crocidura leucodon (Herm.). Z. Säugetierkunde, 4: 157-185.

43. Zippelius H., 1957: Zur Jugendentwicklung der Waldspitzmaus, Sorex araneus Bonn. zool. Beitr., 9: 120-129.

Received 20 April 1986, Accepted 25 March 1987.

Iwona MICHALAK

WZROST I ROZWOJ POSTNATALNY RZESORKA RZECZKA

Streszczenie

Dysponowano materiałem 27 miotów (185 młodych) Neomys fodiens Pennant, 1771 urodzonych $\mathrm{w}$ warunkach hodowli laboratoryjnej, przy czym 117 mlodych $\mathrm{z}$ 20 miotów zostało odchodowanych przez samice aż do uzyskania pełnej samodzielności.

Noworodki $N$. fodiens były nagie, barwy ciemnoczerwonej i ważyły średnio $0.62 \mathrm{~g}$ (Tabela 1), pigment w skórze grzbietu pojawiał się w 5 dniu życia młodych a w skórze brzucha w 9 dniu, u 6-dniowych młodych można było określić płeć (u samic widoczne były ciemne plamki pigmentu wokół sutek), w 9 dniu na grzbiecie wyrastaly włoski widoczne golym okiem, w 11 dniu grzbiet pokrywała milimetrowa, lśniąca sierść a w 20-25 dniu sierść stawała się matowa (Tablice VIII i IX). Proces rozchodzenia się palców zachodził między 13 a 19 dniem, przy czym wcześniej uwalnialy się palce kończyn przednich (Ryc. 1). Oczy otwieraly się między 20 a 24 dniem (Ryc. 2). W 25-27 dniu wyrzynały się siekacze. Młode wychodziły z gniazda w 23-26 dniu (Ryc. 4). Pierwszym pokarmem młodych poza mlekiem matki było mleko zszalek ( $24-27$ dzień) zaś pokarm stały zaczynały jeść w $27-30$ dniu (Ryc. 4). Sredni czas trwania laktacji wynosil 38 dni $(\min =32, \max =41$ dni).

Najwyższe tempo przyrostu masy ciała miało miejsce w ciągu pierwszych dwóch tygodni życia młodych (Ryc. 5). W 10-11 dniu życia masa młodych była około 
10-krotnie większa od masy noworodków a w dniu wyjścia $\mathrm{z}$ gniazda młode ważyły średnio 19.4 raza więcej od noworodków (Ryc. 6). W okresie między wyjściem młodych z gniazda a pobraniem pierwszego pokarmu stałego, obserwowano u młodych spadek masy ciała lub przynajmniej zahamowanie dalszego jej przyrostu (Ryc. 4).

Przeprowadzono dyskusję na temat sposobów określania ezasu trwania laktacji u Soricidae oraz wyznaczania wieku „weaning" jak i poruszono kwestię pojmowania sensu terminu ,weaning”.

Porównano tempo przyrostu masy ciała ryjówek należących do dwóch podrodzin (Soricinae, Crocidurinae) stwierdzając, że u Crocidurinae występują cięższe noworodki (w stosunku do masy adultus) i wolniejsze jest tempo przyrostu masy ciała (Tabele 6 i 7 ). 
Appearance of Neomys fodiens (natural size) on successive days of their postnatal life. Figures designate the age of young in days.

Photo A. Nursing female on day 30 of rearing the litter. Note the elongated nipples and nacked skin around them. 


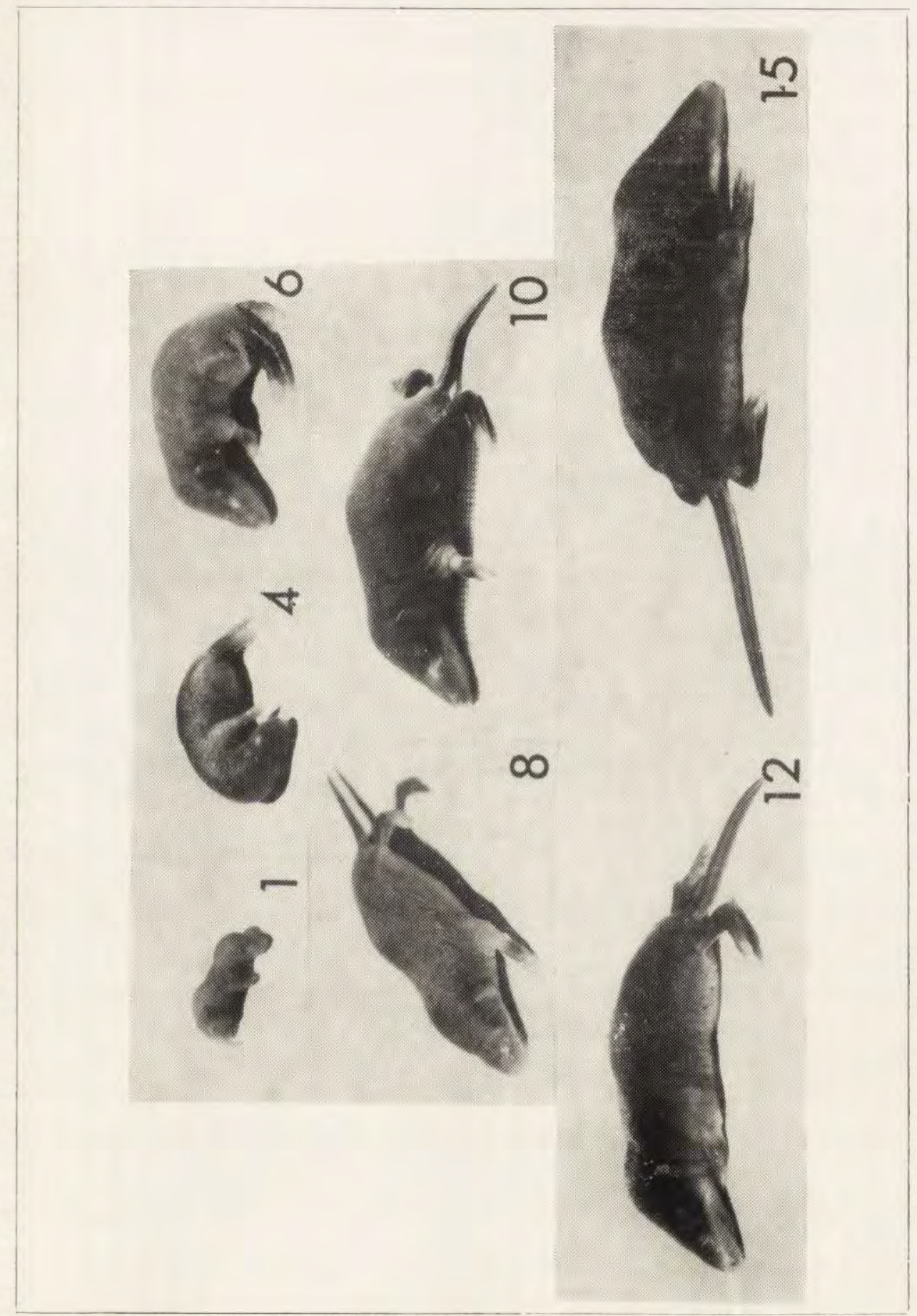




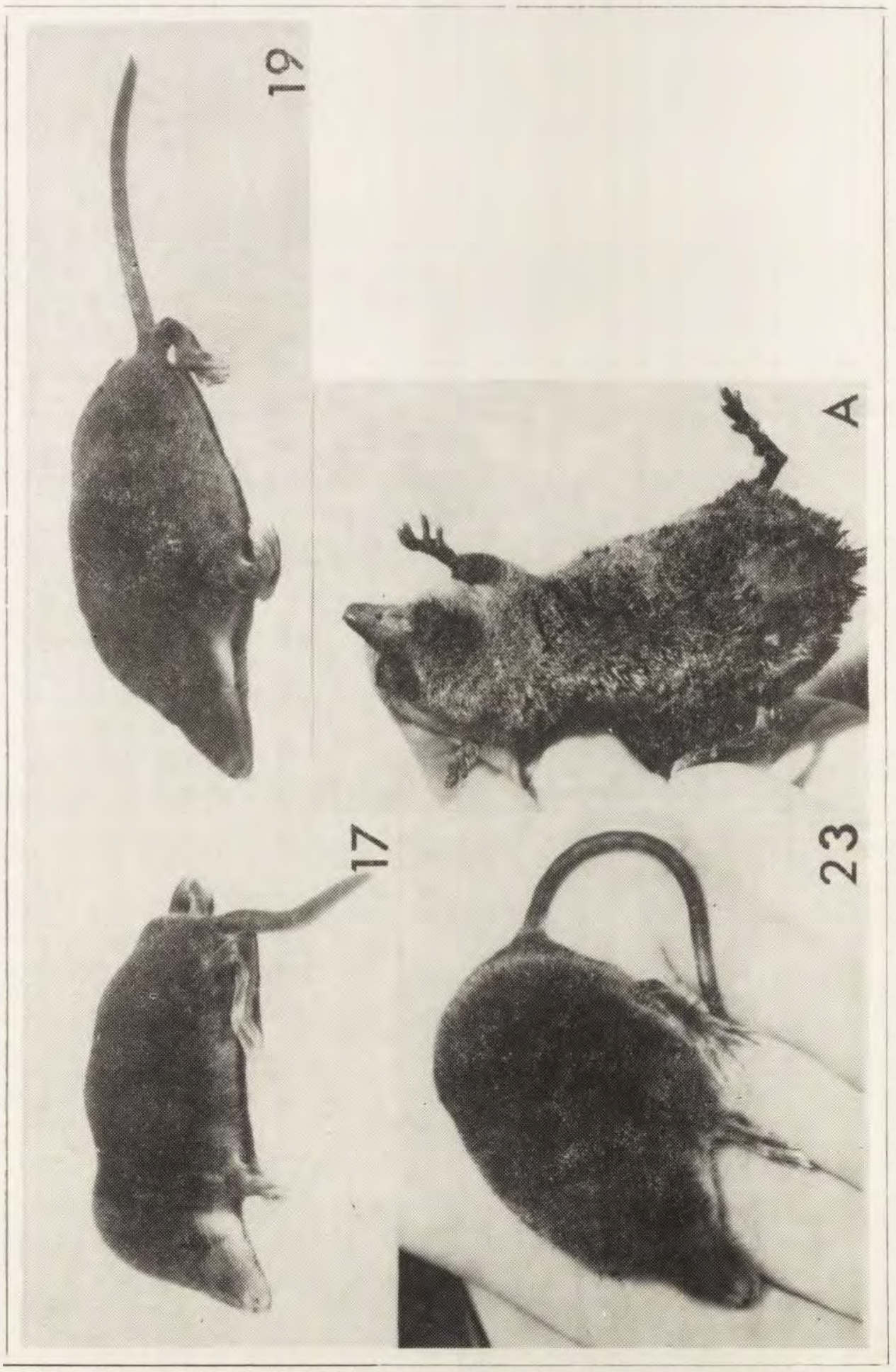

